\title{
Entrepreneurial Orientation and Innovation for Improving Competitive Advantage
}

\author{
Anton Mulyono Azis*, Maya Irjayanti, and Resi Juariah Susanto \\ School of Management, Ekuitas Business School \\ Jl. PHH. Mustopa No. 31 Bandung-Indonesia
}

\begin{abstract}
This study aims to identify the entrepreneurial orientation and innovation in maintaining the business continuity and competitive advantage, especially in the small and medium enterprises in the Binong Jati Knitting Industry Center Bandung. The research method used is descriptive analytical with qualitative approaches, in order to know entrepreneurial orientation and innovation of entrepreneurs. The research was conducted through surveys and interviews with craftsmen, the owner of the home industry, customers, and other related parties of knitting industry stakeholders. From the results of the study obtained that competitive advantage, which is indicated by the ability to face the threat of new products or substitute products, as well as challenges from suppliers, customers, and competitors' strategies; can be improved through entrepreneurial orientation and innovation. There are three indicators on entrepreneurial orientation, namely creative activity, proactive, and courage to take risks, while innovation consists of three indicators, namely product, process, and system innovation.
\end{abstract}

Keywords: Entrepreneurial orientation, Innovation, Competitive advantage, Knitting industry center.

\section{INTRODUCTION}

Rapid changes in technology, customer needs, and product trends cause serious problems for businesses. Businessmen are required to be able to choose and determine the right strategy to maintain competition [1],[2]. This also applies to small and medium enterprises (SMEs) that have a strategic role in national economic development. For this reason, the central role of small and medium entrepreneurs is needed with creativity and innovation [3]-[5], which are expected to make small and medium enterprises ready to face global challenges and supported by entrepreneurial management [6]-[8].

Entrepreneurs are individuals who are able to utilize resources creatively and innovatively [9],[10] and overcome various problems in business competition [11]. So, SMEs play a very strategic role, because of their great potential in driving community activities as well as being the source of income for most of the community [12]. Thus, various obstacles and problems that often arise in small and medium enterprises must be overcome.

Furthermore, researcher identified various shortcomings and problems faced by MSMEs based on their priorities, namely: (a) lack of capital (b) difficulties in marketing, (c) inability in business competition, (d) difficulties in raw materials, (e) lack of technical production and expertise, (f) lack of managerial skills, and (g) lack of knowledge in management issues especially in finance and accounting [3].

With these various problems requires every businessman thinks of the right competing factors so that the business could continue [13]. Thus the purpose of this study is to identify entrepreneurial orientation and innovation in maintaining business continuity and competitive advantage, especially in the small and medium businesses of Binong Jati Bandung knitting industry.

*Corresponding Author: Anton Mulyono Azis, School of Management, Ekuitas Business School Jl. PHH. Mustopa No. 31 BandungIndonesia, email: anton.mulyono@ekuitas.ac.id 
Aton, Maya \& Resi/ Journal of Engineering and Science Research, 3(2) 2019, Pages: 01-07

\section{LITERATURE REVIEW: IMPORTANT ROLE OF ENTREPRENEURIAL ORIENTATION AND INNOVATION}

The importance of competitive advantage to improve business performance is inseparable from entrepreneurial orientation [14]. Entrepreneurial orientation is proven to have an impact on company performance which is the forerunner of forming competitive advantage in the company [15]. Of course, the company's orientation is influenced by the entrepreneur's personal value as the company's main navigator. Personal values are the core of diverse human behavior where human decisions and actions are manifestations of these values [16]. There is a relationship between values, attitudes, and behavior that has been recognized in many studies, especially in the field of entrepreneurship and management [17]. One research showed that there is agreement among most researchers that personal values are predictors of actual behavior through instrumental concepts such as desire, attitude, or intention [18].

Entrepreneurial behavior has an important role in explaining the company's strategic behavior [14]. Entrepreneurship behavior is of course influenced by the values of individual entrepreneurship which are reflected in the way they run the company which will then connect it to the strategic level of the company to be achieved. Research has proven that entrepreneurial orientation is considered a central domain in entrepreneurial activities [19]. Entrepreneurial orientation is considered to represent policies and practices that are the foundation for conducting entrepreneurial activities. In other words, entrepreneurial orientation is the strategic thinking of an entrepreneur to set company goals through a particular vision that will create a competitive advantage in its products [19].

Entrepreneurial orientation is a significant contributor to the success of a company, with dimensions of creativity, innovation, and courage in facing risks that are carried out by working hard to form and maintain new businesses [15]. Furthermore, the researcher states that entrepreneurship education can improve ways of thinking and acting to achieve maximum results in business [20]. This is also supported by the research which proved that entrepreneurial orientation has a significant positive effect on improving the competitiveness of SMEs which are dominated by good strategies [21].

Furthermore, besides focusing on entrepreneurial orientation, innovation activities are more specific approaches that companies must do in order to increase competitive advantage [22]. Innovation is the key to maintaining a competitive advantage by combining knowledge with making new products [23]. Innovation can also include the use of the latest technology or implementing new ways in the company's production processes in competition in the same market, where entrepreneurs make innovative steps even though the company still faces the same competitors and struggles on the same market scale.

Furthermore, to innovate, companies need to expand their resources, knowledge, and relationships through a system of collaboration or network expansion. Of course, innovation is a risky step because the company not only invests in knowledge but also costs. Therefore, innovation is a risky decision, especially for small-scale companies. Therefore, innovation requires open and positive thinking from the businessman. Innovation can also manifest in various forms, including the design of new products, new production processes, improvement of marketing strategies, and new ways of implementing training programs [22].

Customers will leave companies that do not innovate. Without innovation, the company will not last long. Customers will not always consume the same product by looking for other products that can satisfy their needs. Furthermore, several studies stated that product innovation has a positive and significant effect on competitive advantage [24],[25]. Moreover, competitive advantage has been proven to have an impact on improving company performance [26]. Competitive advantage is not only useful for identifying potential aspects of a company but also useful for mapping performance and comparisons of different types of companies [27],[28]. Nowadays, company managers have been required to increase their awareness of the importance of having a competitive advantage as a company-specific identity [29]. Competitive advantage has become very important because the concept has become a strategic foundation of management in various types of companies [30]. The scope of the company's business strategy to achieve a competitive advantage is to determine a long-term action plan so that the company can pursue its performance targets. For this reason, competitive advantage is widely accepted in strategic management courses and textbooks as important concepts in business strategy.

The factors of competitive advantage are not only able to distinguish a company from its competitors but also provide a unique position in the market. By having a competitive advantage, the company will be able to provide value for its products to customers compared to its competitors [30]. Competitive advantage will lead to achieving profit according to plan, increasing market share, increasing customer satisfaction, and the survival of business [26]. 


\section{RESEARCH METHODOLOGY}

The research was conducted to provide a complete picture of entrepreneurial orientation and innovation of knitting entrepreneurs, so that this study was descriptive analytical, with a qualitative approach. This research is expected to increase the competitiveness of small and medium enterprises in the knit sector. The descriptive analytical approach is conducted to determine the characteristics of the variables under study, namely entrepreneurial orientation, innovation, and competitive advantage, which are related to a particular situation in order to describe aspects relevant to the phenomenon of research [31].

This qualitative research instrument is carried out by conducting interviews with craftsmen, home industry owners, customers, and other related parties in depth to those directly involved in research, including: company management, workers, up to the distribution agents and consumers of finished goods, as well as tracking the results of previous studies, company annual reports, data centers of the knitting industry, and others. So that data is collected through primary and secondary sources.

The analysis unit of this study is small and medium entrepreneurs engaged in knitting production in Bandung. Determination of the sample is based on the relevance of the respondent to the information obtained in this study (theoretical sampling). The number of respondents was chosen 12 or more until the data obtained reached saturation based on the adequacy of information and the absence of new findings obtained during interviews of all respondents.

The data processing is done using Nvivo Pro 11 software to organize data to define concepts and relationships between entrepreneurial orientation and innovation to the competitive advantage of small and medium knitting businesses in Bandung.

\section{FINDINGS AND DISCUSSIONS}

Entrepreneurial orientation essentially is a process, structure, and corporate taking that are reflected in their ability to carry out innovation activities, show proactive behavior, and the courage to take risks [15]. As a research finding, in conducting innovation activities, companies have a tendency to be creative and dare to experiment in creating products, services, or process development. Of course, in innovation activities, companies allocate productive time for research and development activities. Meanwhile, a proactive attitude is an initiative of the company to investigate and monitor opportunities carefully with the aim of moving better and faster than competitors. Through a proactive attitude, companies can create profits as first movers by becoming the first in a variety of ways, including the first to enter the market, first to establish brand identity, first to implement a new process, first to put forward ideas for new procedures, or parties first to dare to adopt new technology [15].

The third, risk-taking is a character that is always found in many successful companies. Taking risks is a bold act carried out on uncertainty and ambiguity. Many business actors are reluctant to take risks because of uncertainty about the success of the decision in the future. Therefore many of them choose to remain in a safe zone that has certainty. This type of entrepreneur certainly does not guarantee a significant business development; if there is one, it will require a relatively longer time than those who dare to take risks when making decisions in their business. This risk-taking includes accepting third-party loans or making significant resource commitments.

Furthermore, competitive advantage is created after companies find new ways or operate more efficiently to enter into the industrial competition [32]. As a research finding, company innovation comes from five main aspects, namely the adoption of new technology, modifying demand or creating market demand, creating new segments, making improvements in aspects of cost or availability of production equipment, and where possible making regulatory changes.

Various innovative approaches can be carried out by the company. Figure 1 shows the approaches taken to innovation. 


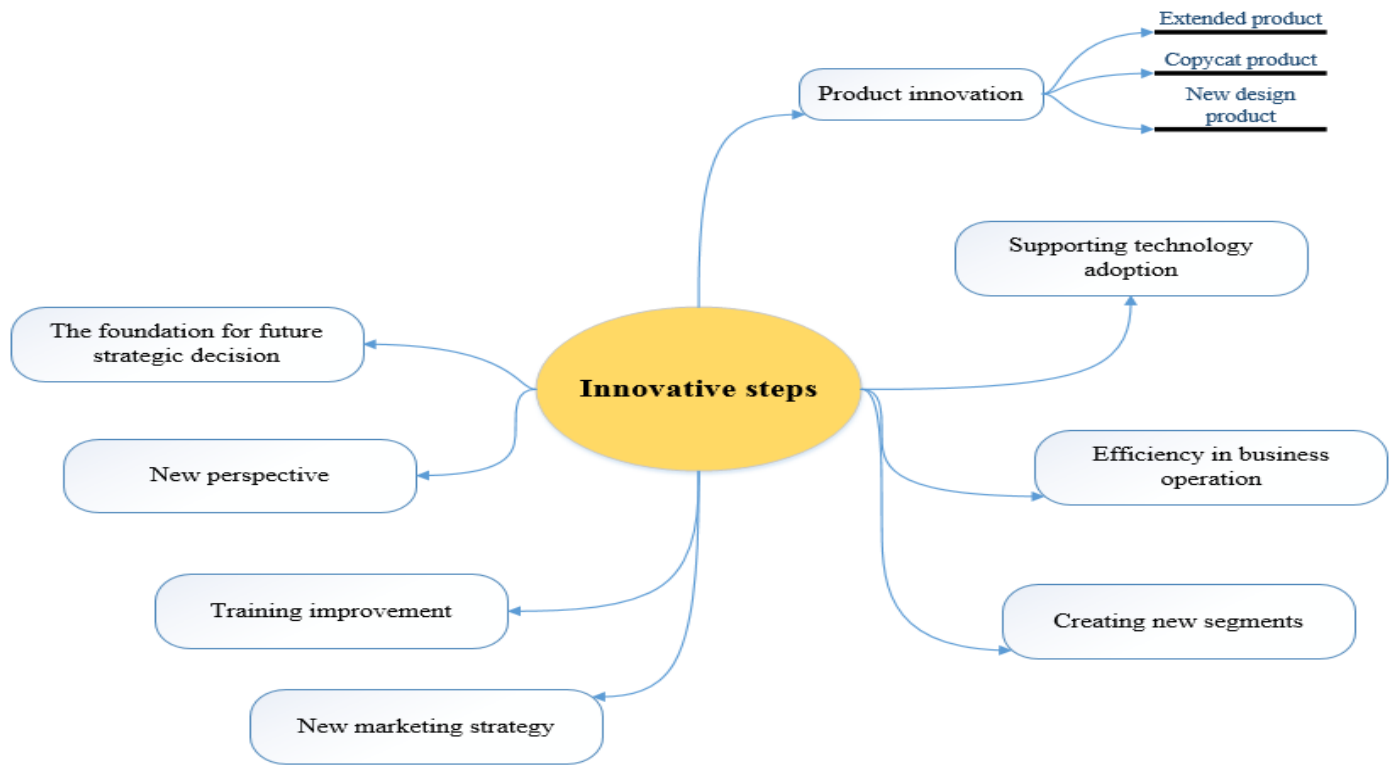

Fig. 1 Innovation Approaches

Fig. 1 showed several options could be a business alternative for making improvements through innovation approach. Innovation can be either straightly or indirectly related to product creation. Through product innovation, a business usually develops the existing product or makes a product adjustment into particular forms that are presently favored by most consumers. Some businesses did extreme innovation which ultimately changes the product design so their customers can experience a new feeling. Furthermore, innovation can be transformed into processes that are indirectly related to product creation. This innovation includes process innovations which usually consist of technological innovation, process efficiency, improvement in employee training, apprising marketing strategies, creating new customers' segmentations, changing the mindset of the company, or constructing innovations based on the preceding innovations.

Moreover, the innovative approach is not limited to the aspects shown in Fig. 1. The company needs to recognize its business character first and the potential that can be strengthened to become a competitive advantage. Micro or small scale businesses certainly do not focus on innovations that have the potential to drain their costs, such as updating staff training, they can focus on other potential aspects that make sense to be implemented.

Against a variety of limitations faced by micro and small scale businesses, innovation activities focus on two approaches, namely product innovation and process innovation. However, many technologies were created to accommodate various types of business scale. Micro, small and medium scale businesses need to consider technological adaptation as one of their innovations in expanding the market. Especially information technology can be a solution for businesses with limited funds in conducting promotions and renting shop places

In an effort to maintain business or anticipate increasing competition, a business must continue to develop its business by carrying out product innovations and process innovations [33]. In deciding to innovate, of course, an entrepreneur needs to identify substantial factors in his efforts to make improvements. The improvements made not only refer to the analysis of processes that do not meet the criteria, but also the improvement of processes that have become better, more efficient, and more innovative.

Innovation is a step that supports efforts to improve business continuity in the long run. Innovation will not only make a business survive in competition but also provide a unique business identity. This distinctive identity will ultimately be the competitive advantage of the business. Unfortunately, not all companies can optimize the potential of their competitive advantage. Generally, they focus on processes that already exist or that are commonly carried out by other similar businesses.

Furthermore, product innovation is also a factor that must be considered in increasing competitiveness. Innovation is an idea, practice, or object that is realized and accepted as something new by a group to be adopted [34]. There are several indicators of product innovation found in research, namely: product extensions (line 
extensions), me-too products, or new-to-the-world products. Innovation is an alternative for organizations to develop and survive dynamically and adapt to the environment that can lead to greater levels of competition [22].

As the main result, a competitive advantage does not only belong to large companies; SMEs also experience in a smaller scope. They also deal with various threats from competitors, consumers, suppliers, new players in the market, and substitute products. Therefore, identifying what is a competitive advantage also needs to be done to maintain and expand the current market share.

This study has identified competitive advantages in small and medium enterprises, especially in the knitting industry, through the identification of entrepreneurial orientations and business innovations that are used to identify potential aspects and then become the competitive advantage of the business, as shown in Fig. 2 .

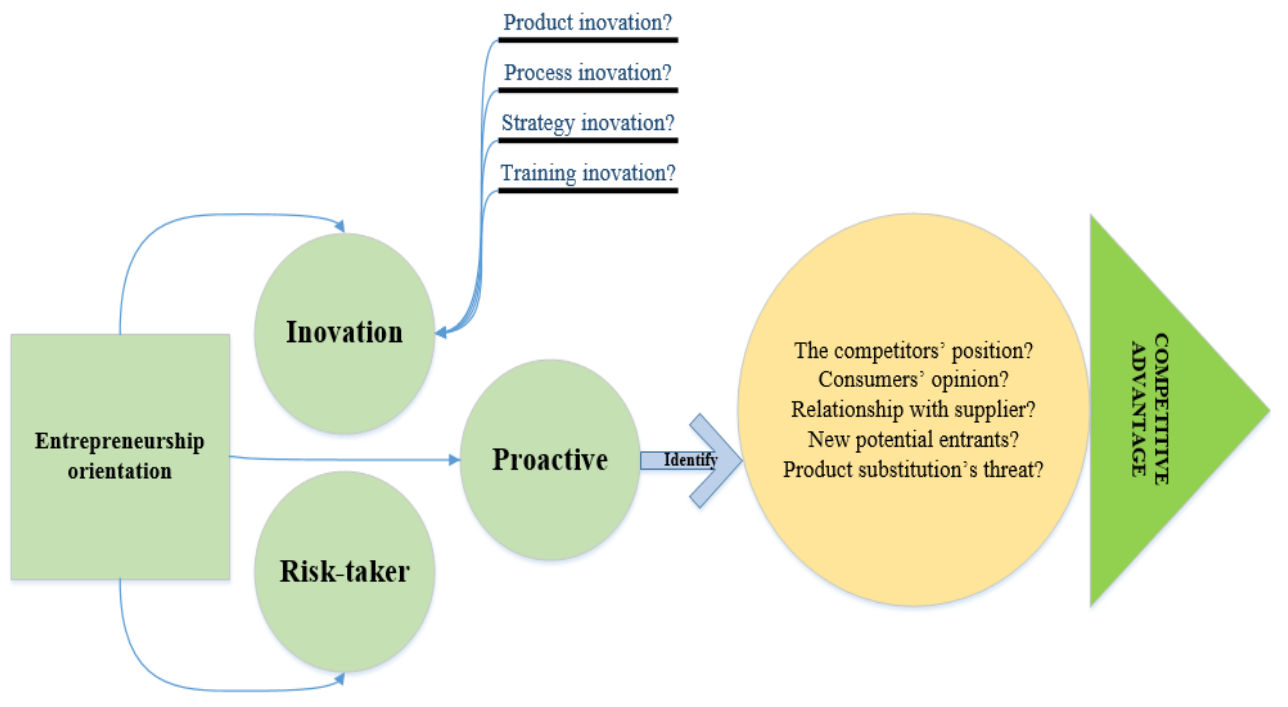

Fig. 2 Impact of Entrepreneurship Orientation and Innovation on Competitive Advantages

Fig. 2 provides an illustration of how entrepreneurial orientation relates to innovation activities that impact the company's competitive advantage. There are several factors included in the entrepreneurship orientation. These three categories that most likely mentioned in the relevant literature are innovation, risk-takers, and proactive attitudes. Innovation indeed has a significant impact on the business from various aspects. Certainly, two positive characters such as the courage to take risks and being proactive in the competition are essential supporting factors to improve business performance. The combination of these factors within entrepreneurship orientation will help to navigate the businesses' strengths in the competition. The business will easily recognize and distinguish its capability in the market competition; then, they will acknowledge which portion that requires improvement and what potential needs to be developed into a competitive advantage.

Competitive advantage does not always appear in the eyes of consumers; sometimes superior companies compete in aspects of their ability to reduce production costs. This is advantageous because companies can sell products at the same price but with lower production cost than competitors. With this aspect, companies can acquire larger amounts of profits to expand their business. Of course, a solid business will gain the trust of its customers, especially those who have become consumers of these products in a relatively long time.

Creating competitive advantage is a difficult job that requires time and costs. It was initially formed by managing resources to provide goods and services in accordance with the needs and desires of consumers. In some cases, companies make improvements in aspects of the process by reducing costs in the supply of goods and services. Nowadays, it is more difficult to maintain the existence of a business than to create a new company. Costs incurred to create a new business will be more expensive than the investment spent to maintain it.

Thus, the low attention to the role of the company's competitive advantage, not only can affect the 
company's performance but also risks threatening business continuity within a certain period of time. This is due to the significant impact of competitive advantage on the company's financial performance [26] in addition to other performance aspects.

Companies that do not have competitive advantages usually have various internal problems in their operational activities [35],[36]. Evidently, nowadays, Small and Medium Enterprises (SMEs) in Indonesia are difficult to develop because they face several internal problems, namely the low quality of human resources such as lack of skilled human resources, lack of entrepreneurial orientation (entrepreneurial orientation), low mastery of technology and management, and lack of information.

\section{CONCLUSION}

Competitive advantage can be achieved by entrepreneurial orientation and innovation. Entrepreneurial orientation is reflected in individuals who taunt to make difficult decisions and take risks. A person who takes risks can be defined as someone who has an orientation to opportunities in uncertainty condition. This is indicated by the direct influence of entrepreneurial orientation which consists of innovative, proactive and risk-taking attitudes towards increasing competitive advantage while innovations can be carried out, among others, through the adoption of new technologies, modifying or creating market demand, creating new segments, and making improvements in cost or production equipment.

\section{REFERENCES}

[1] P. Larsen and A. Lewis, "How award-winning SMEs manage the barriers to innovation", $J$. Creativity and Innovation Management, pp. 141151, 2007.

[2] I. Pearce, A. John, and R.B. Robinson, "Strategic Management: Formulation, Implementation and Control", Twelfth Edition, 2011.

[3] E. Hadiyati, "Kreativitas dan inovasi berpengaruh terhadap kewirausahaan usaha kecil". J. Manajemen dan Kewirausahaan, vol. 13, no. 1, pp. 8-16, 2011.

[4] B. Prakosa, "Pengaruh orientasi pasar, inovasi dan orientasi pembelajaran terhadap kinerja perusahaan untuk mencapai keunggulan bersaing (Studi empiris pada industri manufaktur di Semarang)", J. Studi Manajemen dan Organisasi, vol.2, no.1. pp. 35-57, 2005.

[5] Suryana, "Kewirausahaan: Pedoman praktis: Kiat dan Proses Menuju Sukses", 3th ed. Jakarta. Penerbit Salemba Empat, 2008.
[6] S. Echdar, "Manajemen Entrepreneurship: Kiat Sukses Menjadi Wirausaha", Jogyakarta: Penerbit Andi, 2013.

[7] G. Hills, "Marketing and entrepreneurship, research ideas and opportunities", J. of Small and Medium Entrepreneurship, pp. 27-39, 2008.

[8] G. Knight, "Entrepreneurship and marketing strategy: the SME under globalization". J. of International Marketing, vol.8, no.2, pp.12-32, 2000.

[9] N.N. Afiah, "Peran kewirausahaan dalam memperkuat ukm indonesia menghadapi krisis finansial", Working Paper In Accounting and Finance, Faculty of Economics Padjadjaran University, Bandung, 2009.

[10] D.F. Kuratko, "Introduction to Entrepreneurship", Eight Edition. Cengage Learning, Canada, 2009.

[11] S. Gunawan and R.R. Ardianti, "analisa entrepreneurial motivation dan inovasi produk pada pelaku usaha mikro dan kecil di Jawa Timur pada sektor informal". AGORA, vol. 1, no. 3, 2013.

[12] M. Isa, M, "Pengukuran efisiensi teknis usaha mebel dengan data envelopment analysis (DEA)", BENEFIT, vol. 11, no. 1, pp.1410-4571, 2007.

[13] R.P. Suci, "Peningkatan kinerja melalui orientasi kewirausahaan, kemampuan manajemen, dan strategi bisnis (Studi pada industri kecil menengah bordir di Jawa Timur), J. Manajemen dan Kewirausahaan, vol.11, no.1, pp. 46-58, 2009.

[14] J.S. Soininen, K. Puumalainen, H. Sjögrén, P. Syrjä, and S. Durs, "Entrepreneurial orientation in small firms - values-attitudes-behavior approach", Int. J. of Entrepreneurial Behavior \& Research, vol. 19, no. 6, pp. 611-632, 2013.

[15] D. Mullens, "Entrepreneurial orientation and sustainability initiatives in family firms", $J$. of Global Responsibility, vol 9, no. 2, pp. 160-178, 2018.

[16] A. O. O. Uy, "What motivates entrepreneurs? A study of the value systems of Filipino entrepreneur". Int. J. of Entrepreneurship, no. 15, pp. 73-95, 2011.

[17] P. E. Connor and B. W. Becker, "Personal value systems and decision-making styles of public managers". Public Personnel Management, vol. 32, no. 1, pp. 155-180, 2003.

[18] C. A. Hemingway, "Personal values as a catalyst for corporate social entrepreneurship", J. of Business Ethics, vol. 60, no. 3, pp. 233-249, 2005.

[19] A. Rauch, J. Wiklund, G. Lumpkin, and M. Frese, "Entrepreneurial orientation and business performance: Cumulative empirical evidence", 2009.

[20] A. Fayolle, "Handbook of research in entrepreneurship education: A general perspective", vol. 1, Edward Elgar Publishing, 2007. 
[21] Andriyani, "Analisis pengaruh orientasi kewirausahaan terhadap strategi pemasaran guna meningkatkan kinerja perusahaan", Thesis: Universitas Diponegoro, Semarang, 2005.

[22] M. E. Porter, "Competitive advantage: creating and sustaining superior performance", Simon and Schuster, 2008.

[23] J. Hardwick, D. Cruickshank, and A. R. Anderson, "Innovation in small business: comparing face-toface with virtual networking", J. of Business Strategy, vol. 33, no. 5, pp. 51-58, 2012.

[24] C. V. Djodjobo and H. N. Tawas, "Pengaruh orientasi kewirausahaan, inovasi produk, dan keunggulan bersaing terhadap kinerja pemasaran usaha nasi kuning di kota Manado", J. Riset Ekonomi, 2014.

[25] H. Setiawan, "pengaruh orientasi pasar, orientasi teknologi dan inovasi produk terhadap keunggulan bersaing usaha songket skala kecil di kota Palembang", J. Orasi Bisnis, no. 8, 2012.

[26] N. Kamukama, A. Ahiauzu, and J. M. Ntayi, "Competitive advantage: mediator of intellectual capital and performance", J. of Intellectual Capital, vol. 12, no. 1, pp. 152-164, 2011.

[27] M. Ceccagnoli, "Appropriability, preemption, and firm performance”. Strategic Management J, vol. 30, no. 1, pp. 81-98, 2009.

[28] C. Zott and R. Amit, "The fit between product market strategy and business model: implications for firm performance", Strategic management J., vol. 29, no. 1, pp. 1-26, 2008.
[29] C. Sigalas, "Competitive advantage: the known unknown concept", Management Decision, vol. 53, no. 9, pp. 2004-2016, 2015.

[30] M. Baaij, M. Greeven, and J, Van Dalen, "Persistent superior economic performance, sustainable competitive advantage, and Schumpeterian innovation: Leading established computer firms, 1954-2000", Eur. Management J. vol. 22, no. 5, pp. 517-531, 2004.

[31] U. Sekaran, "Research Methods for Business", Jakarta: Salemba Empat, 2014.

[32] D. Passemard and B. H. Kleiner, "Competitive advantage in global industries", Management Res. News, vol. 23, no. 7/8, pp. 111-117, 2000.

[33] A. Kocak, A. Carsrud, and S. Oflazoglu, "Market, entrepreneurial, and technology orientations: impact on innovation and firm performance", Management Decision, vol. 55, no. 2, pp. 248-270, 2017.

[34] S. P. Robbins and T. Judge, "Essentials of organizational behavior", Pearson Education Inc., 2012.

[35] L. Saiman. "Kewirausahaan: Teori, praktik, dan kasus-kasus", Jakarta: Salemba Empat. 2009.

[36] T. T. H. Tambunan and K. McKague, "Development of small and medium enterprises in a developing country", "J. of Enterprising Communities: People and Places in the Global Economy, vol. 5, no. 1, pp. 68-82, 2011. 